\title{
PENINGKATAN KECERDASAN INTERPERSONAL ANAK USIA DINI MELALUI PERMAINAN TRADISIONAL
}

\section{Increasing Early Childhood Interpersonal Intelligence through Indigenous Games}

\author{
Nurfitri Sahidun ${ }^{1}$ \\ ${ }^{1}$ Institut Agama Islam Negeri (IAIN) Ternate, Ternate, Indonesia \\ ${ }^{1}$ Email: nurfitriperdana@gmail.com
}

\begin{abstract}
Abstrak
Tujuan penelitian ini adalah untuk mendeskripsikan proses pelaksanaan kegiatan bermain permainan tradisional dan menganalisis hasil peningkatan kecerdasan interpersonal anak usia dini kelompok A PAUD Titian Kasih melalui kegiatan bermain permainan tradisional. Metode penelitian yang digunakan adalah metode Kemmis dan Taggart yang terdiri dari perecanaan, tindakan, observasi, dan refleksi. Teknik pengumpulan data yang digunakan adalah observasi, wawancara, dan dokumentasi. Responden dalam penelitian adalah 12 orang anak dari kelompok A PAUD Titian Kasih, Ternate. Hasil Penelitian menunjukkan bahwa kecerdasan interpersonal anak meningkat melalui kegiatan bermain permainan tradisional sebesar $46,96 \%$ dari pre test menjadi $79,92 \%$ pada hasil posttest siklus II.

\section{Kata kunci: Kecerdasan Interpersonal, Permainan Tradisional, Anak Usia Dini \\ Abstract}

The aims of this research are to describes the process of implementation playing activities by indigenous game and to analysis the increasing early childhood interpersonal intelligence at Group A PAUD Titian Kasih through playing activities traditional games. Research Method used by Kemmis and Taggart model. It consist of planning, acting, observation, and reflection. Data collecting techniques use observation, interview, documentation. Respondent of the research involved are 12 children of group A PAUD Titian Kasih, Ternate. The result of this research shows that students interpersonal intelligence were increasing from $46.96 \%$ pretest up to $79.92 \%$ posttest result at cycle II.
\end{abstract}

Keywords: Interpersonal Intelligence, Traditional Games, Early Childhood

Submitted: 21 Februari 2018, Accepted: 1 April 2018, Published:2 April 2018

\section{PENDAHULUAN}

$\mathrm{P}$ endidikan Anak Usia Dini bertujuan untuk membantu anak didik mengembangkan berbagai potensi baik psikis dan fisik yang meliputi moral dan nilai agama, sosial emosional, kemandirian, kognitif, bahasa, fisik/motorik, dan seni untuk siap memasuki sekolah dasar. Pengembangan berbagai potensi tersebut sejalan dengan konsep kecerdasan Howard Gardner yang disebut dengan Multiple Intelligences (kecerdasan majemuk atau kecerdasan jamak). Kecerdasan dalam Multiple Intelligences meliputi kecerdasan visual spasial, kecerdasan musikal, kecerdasan kinestetik, kecerdasan interpersonal, kecerdasan intrapersonal, kecerdasan naturalis, dan kecerdasan eksistensial. Salah satu kecerdasan yang penting dalam aspek perkembangan sosial anak adalah kecerdasan interpersonal.

Kecerdasan interpersonal adalah kecerdasan yang ditunjukkan dengan kemampuan anak dalam bersosial dengan orang lain dengan baik, seperti mudah bergaul, memahami orang lain, dan bekerja sama dengan orang lain (Suyadi, 2014; Mulyasa, 2014; \& Amstrong, 2009). Seseorang dengan kecerdasan interpersonal mampu bersosial dengan baik, karena kecerdasan interpersonal merupakan kemampuan untuk berhubungan dengan orang lain (Suyadi, 
2014). Hal ini penting bagi semua orang karena dengan kecerdasan interpersonal seseorang mampu bekerja sama dengan orang mudah.

Upaya pengembangan yang dapat dilakukan untuk anak usia dini adalah melalui bermain, salah satunya adalah bermain permainan tradisional. Bagi anak usia dini, bermain merupakan kegiatan keseharian mereka (Dewantara, 1977). Bermain dapat mempengaruhi semua perkembangan dengan memberikan kesempatan kepada anak untuk belajar tentang dirinya sendiri, orang lain dan lingkungan. Anak bermain untuk memperoleh sesuatu dengan cara bereksplorasi dan bereksperimen tentang dunia sekitarnya dalam rangka membangun pengetahuan diri sendiri memuaskan tuntutan dan kebutuhan berbagai perkembangan anak bermain mendorong seluruh aspek perkembangan anak: emosional, sosial, intelektual, linguistik, dan fisik (Latif, dkk, 2013; Hoorn, dkk. 2007).

Bermain menggunakan permaian tradisional telah terbukti dapat menstimulasi keterampilan sosial anak usia dini (Seriati, N. N., \& Hayati, N., 2012). Permainan tradisional merupakan salah satu tradisi yang beredar secara lisan dan turun temurun serta banyak mempunyai variasi sehingga permainan tradisional dipastikan usianya sudah tua, tidak diketahui asal usulnya juga tidak diketahui siapa yang menciptakan permainan tersebut (Danandjaya, 1987).

Permainan merupakan simbiolisasi dari pengetahuan yang turun temurun dan mempunyai bermacam-macam fungsi atau pesan dibaliknya, dimana pada prinsipnya permainan anak tetap permainan anak. Permainan tradisional ini tumbuh dan berkembang di tengah-tengah masyarakat sesuai dengan kebutuhan masyarakat setempat dan kondisi alam sekitarnya. Nilainilai budaya yang terkandung dalam permainan tradisional menurut Dharmamulya antara lain melatih sikap mandiri, berani mengambil keputusan, penuh tanggung jawab, jujur, sikap dikontrol oleh lawan, kerjasama, saling membantu dan saling menjaga, membela kepentingan kelompok, berjiwa demokrasi, patuh terhadap peraturan, penuh perhitungan, ketepatan berpikir dan bertindak, tidak cengeng, berani, bertindak sopan, dan bertindak luwes (Ismail, 2006).

Berdasarkan hasil observasi yang dilakukan di kelompok A PAUD Titian Kasih menunjukan bahwa kecerdasan interpersonal 8 dari 12 anak masih rendah. Penyebab kondisi tersebut dikarenakan kurangnya variasi guru dalam melakukan metode pembelajaran dalam proses belajar mengajar. Selain itu anak-anak kurang diberikan kesempatan untuk mengungkapkan atau menyampaikan pendapatnya. Hal ini menjadi keseriusan peneliti dalam mencoba menawarkan kegiatan bermain permainan tradisional untuk meningkatkan kecerdasan interpersonal di kelompok A PAUD Titian Kasih.

\section{METODE}

Penelitian ini menggunakan metode penelitian tindakan (action research) model Kemmis dan Taggart, yang meliputi perencanaan, tindakan, pengamatan dan refleksi. Tindakan yang diberikan permainan tradisional Ternate berupa permainan boy tampurung, permainan cenge-cenge, dan permainan sem. Data penelitian dikumpulkan dengan menggunakan metode wawancara, observasi dan dokumentasi. Penelitian dilaksanakan pada bulan April-Mei 2017 di Kelompok A PAUD Titian Kasih, TernateMaluku Utara.

\section{HASIL DAN PEMBAHASAN}

Berdasarkan data hasil peningkatan kecerdasan interpersonal anak Kelompok A PAUD Titian Kasih, Ternate-Maluku Utara yang berjumlah 12 anak dapat dilihat dari pra-intervensi dengan rata-rata hasil kecerdasan interpersonal sebesar 46,96\% mengalami peningkatan pada siklus I sebesar 10,37\% mencapai $57,33 \%$. Selanjutnya, dari siklus I ke siklus II mengalami peningkatan sebesar $22,59 \%$ dari $57,33 \%$ menjadi $79,92 \%$.

Berdasarkan hasil pengamatan selama siklus II berlangsung, dapat dianalisis 
sebagai berikut: (a) pada awal kegiatan bermain permainan tradisional, terjadi perubahan pada keterampilan anak untuk mau memberikan pujian kepada temannya ketika bermain bersama (b) pada kegiatan inti bermain permainan tradisional terjadi peningkatan aspek partisipasi yaitu anak mau bermain dengan teman dekat karena sudah banyak anak yang mempraktikkan kecerdasan interpersonalnya dalam hal bermain dengan teman dekat, (c) Pada umumnya hasil prosentase anak yang pada siklus I belum mencapai skor $>71 \%$, pada siklus II beberapa anak tersebut sudah mencapai skor diatas $71 \%$. Sedangkan ratarata kelas sudah mencapai $79,92 \%$ sehingga siklus II ini dikatakan berhasil.
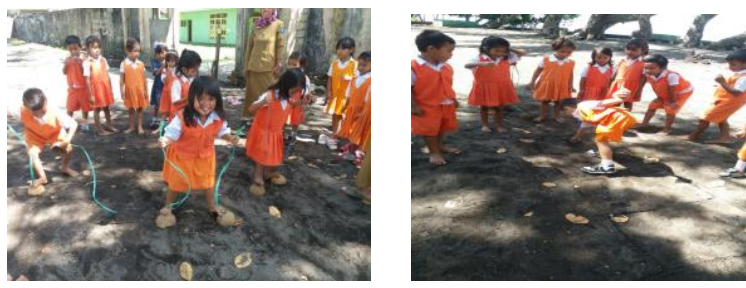

Gambar 1. Anak berpartisipasi aktif dalam kegiatan bermain permainan tradisional

Data hasil pengamatan tindakan yang telah dilakukan terhadap 12 responden pada akhir siklus I, dapat diketahui bahwa kecerdasan interpersonal anak mengalami peningkatan sebesar $10,37 \%$, pada pre test diperoleh rata-rata kelas sebesar 41,33 atau 46,96\% dan pada siklus I menjadi 46 atau 57,33\%. Pada siklus II kecerdasan interpersonal anak semakin mengalami peningkatan sebesar 22,59\%, dimana pada siklus II anak memperoleh rata-rata skor 64,47 atau $79,92 \%$. Hal ini terbukti bahwa kegiatan bermain permainan tradisional dapat meningkatkan kecerdasan interpersonal anak.

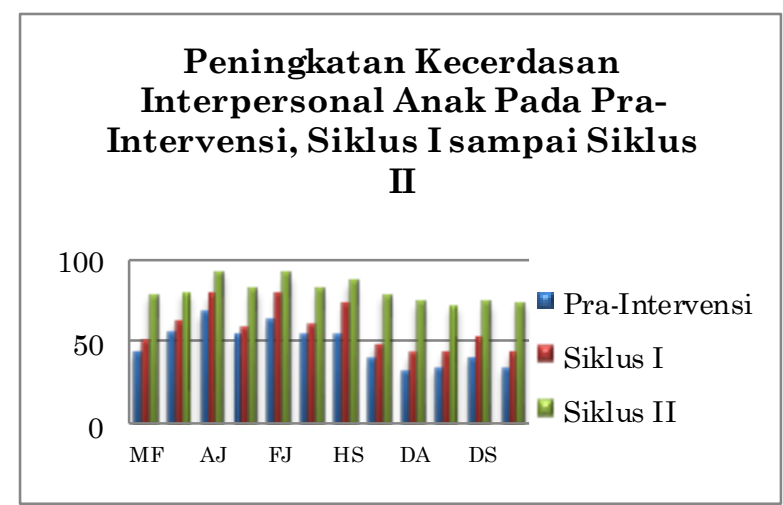

Grafik 1. Prosentase perubahan skor Kecerdasan Interpersonal Anak

Hasil penelitian ini sejalan dengan hasil penelitian-penelitian sebelumnya tentang penggunaan permainan tradisional untuk meningkatkan kecerdasan interpersonal anak. Bermain menggunakan permaian tradisional telah terbukti dapat menstimulasi keterampilan sosial anak usia dini (Seriati, N. N., \& Hayati, N., 2012). Permainan tradisional tersebut memenuhi unsur-unsur dalam hal melatih sikap mandiri, berani mengambil keputusan, penuh tanggung jawab, jujur, sikap dikontrol oleh lawan, kerjasama, saling membantu dan saling menjaga, membela kepentingan kelompok, berjiwa demokrasi, patuh terhadap peraturan, penuh perhitungan, ketepatan berpikir dan bertindak, tidak cengeng, berani, bertindak sopan, dan bertindak luwes (Ismail, 2006).

Beberapa permainan tradisional dari beberapa daerah telah terbukti mampu meningkatkan kecerdasan interpersonal anak (Ningsih, 2017; Wartilah, Zulirfan, \& Risma, 2018). Permainan tradisional lainnya yang mampu mengembangkan kecerdasan interpersonal adalah permainan anjanganjangan, makah-makah dari Banda Aceh, ular naga, pecah piring, dan sunda manda (Kurnia, 2015; Mandira, Aziz, \& Fitriani, 2016; Nasution \& Siregar, 2017; Wardah, 2018)

Permainan tradisional, pada dasarnya merupakan permainan yang kaya akan makna filosofis dan nilai edukasi. Banyak permainan tradisional yang hanya akan bisa 
dilakukan jika bersama-sama dan bekerja sama dengan temannya. Kegiatan bekerja sama dalam suatu permainan itulah wujud dari perilaku sosial. Seseorang dengan kecerdasan interpersonal mampu bersosial dengan baik, karena kecerdasan interpersonal merupakan kemampuan untuk berhubungan dengan orang lain (Suyadi, 2014).

Anak-anak dengan kemampuan yang telah berkembang dalam kecerdasan interpersonal akan dapat belajar melalui hubungan antardiri atau antarindividu. Mereka sama sekali tidak memiliki hambatan untuk membina sosialisasi. Hal ini akan memberikan dampak positif sebagai keterampilan dalam menciptakan relasi, membangun relasi dan mempertahankan relasi sosialnya.

Ada dua faktor yang mempengaruhi kecerdasan interpersonal anak, yaitu faktor hereditas atau faktor intern dan faktor yang berasal dari lingkungan sekitar anak, misal lingkungan masyarakat, lingkungan sekolah dan faktor ini biasa disebut dengan faktor extern. Perkembangan kecerdasan interpersonal anak dipengaruhi oleh sejumlah agen sosial dan afiliasi: rumah dan keluarga, keberadaan anggota keluarga, kepatuhan berbasis kelompok, setting penitipan dan pendidikan anak, teman bermain, tetangga dan media. Faktor yang paling dominan adalah pengaruh kehidupan di dalam keluarga. Seorang anak yang mendapat model kehidupan sosial yang baik dalam keluarganya sejak anak berusia dini, maka di dalam diri anak akan tertanam hal-hal yang positif dalam perkembangan sosial anak tersebut.

\section{SIMPULAN}

Kecerdasan interpersonal anak di kelompok A PAUD Titian Kasih mengalami peningkatan setelah diberikan stimulus dengan kegiatan bermain permainan tradisional (permainan boy tampurung, permainan cenge-cenge, dan permainan sem). Hal ini dilihat dari hasil pra-intervensi dimana kecerdasan interpersonal anak mengalami peningkatan sebesar $10,37 \%$, pada pre test diperoleh rata-rata kelas sebesar
41,33 atau 46,96\% dan pada siklus I menjadi 46 atau 57,33\%. Pada siklus II kecerdasan interpersonal anak semakin mengalami peningkatan sebesar $22,59 \%$, dimana pada siklus II anak memperoleh rata-rata skor 64,47 atau $79,92 \%$. Permainan tradisional yang digunakan dalam penelitian ini yaitu permainan boy tampurung, permainan cengecenge, dan permainan sem; memiliki karakteristik permainan yang mengasah dan mampu memberikan stimulus kepada siswa dalam interaksi teman sebaya berupa partisipasi aktif, beradaptasi berbagi dan berkomunikasi.

\section{DAFTAR PUSTAKA}

Amstrong, Thomas. (2009). Multiple Intelligences in the Classroom. USA Virginia Alexandria: Association for Supervision and Curriculum Development.

Danandjaya, James. (1987). Folklore Indonesia. Jakarta: Gramedia.

Dewantara, Ki Hajar. (1997). Bagian Pertama- Pendidikan. Yogyakarta: Majelis Luhur Persatuan Taman Siswa.

Hoorn, Judith Vand, Etc. (2007). Play at the Center of the Curriculum. New Jersey: Pearson Education.

Ismail, Andang. (2006). Education Games: Menjadi Cerdas dan Ceria dengan Permainan Edukatif. Yogyakarta: Pilar Media

Kurnia, O. D. (2015). Permainan Sunda Manda dan Kecerdasan Interpersonal (Makna Sunda Manda pada Anak Usia Sekolah Dasar). E-Jurnal Skripsi Mahasiswa TP.

Latif, Mukhtar, dkk. (2013). Orientasi Baru Pendidikan Anak Usia Dini: Teori dan Aplikasi. Jakarta: Kencana Prenada Media Group.

Mandira, G., Aziz, M. Y., \& Fitriani, D. (2016). Pengembangan Kecerdasan Interpersonal Anak Usia 5-6 Tahun Melalui Permainan Makah-Makah di TK IT Al-Azhar Banda Aceh. Jurnal Ilmiah Mahasiswa Pendidikan Anak Usia Dini, 1(2). 
Mulyasa, H.E. (2014). Manajemen PAUD. Bandung: Remaja Rosdakarya.

Nasution, R. K., \& Siregar, N. I. (2017). Pengaruh Permainan Tradisional Pecah Piring dan Ular Naga Terhadap Kecerdasan Interpersonal Anak Usia Dini. ANALITIKA, 5(1), 18-25.

Ningsih, S. (2017). Mengembangkan Kecerdasan Interpersonal Anak Usia Dini Melalui Permainan Tradisional (Studi Kasus di TK AL-Akhyar Purwakarta kelompok B). Tunas Siliwangi: Jurnal Program Studi Pendidikan Guru PAUD STKIP Siliwangi Bandung, 2(1), 30-47.

Suyadi. (2014). Teori Pembelajaran Anak Usia Dini Dalam Kajian Neurosains. Bandung: Remaja Rosdakarya.

Seriati, N. N., \& Hayati, N. (2012). Permainan Tradisional Jawa Gerak dan Lagu Untuk Menstimulasi Keterampilan Sosial Anak Usia Dini. Naskah Publikasi.

Wardah, I. Z. (2018). Pengaruh kegiatan sosiodrama dalam permainan tradisional anjang-anjangan terhadap kecerdasan interpersonal anak usia dini (PhD Thesis). UIN Sunan Ampel Surabaya.

Wartilah, W., Zulirfan, Z., \& Risma, D. (2018). Meningkatkan Kecerdasan Interpersonal Melalui Permainan
Tradisional Anak Usia 5-6 Tahun di TK Tunas Harapan Sei Lambu Makmur Kecamatan Tapung Kabupaten Kampar. Jurnal Online Mahasiswa (JOM) Bidang Keguruan Dan Ilmu Pendidikan, 4(1), 1-15.

\section{BIOGRAFI SINGKAT PENULIS}

Nurfitri Sahidun, S.Pd.,M.Pd lahir di TernateMaluku Utara pada tanggal 08 April 1989. Mengawali pendidikan strata satu pada Universitas Khairun Ternate Fakultas Keguruan dan Ilmu Pendidikan Program Studi Pendidikan Bahasa Inggris pada tahun 2008 dan lulus pada tahun 2012. Pada tahun 2013, penulis melanjutkan pendidikan di Program Pascasarjana Universitas Negeri Jakarta Program Studi Pendidikan Anak Usia Dini dan lulus pada tahun 2015. Penulis bekerja sebagai dosen tetap di Institut Agama Islam Negeri (IAIN) Ternate sejak tahun 2015 pada program studi Pendidikan Islam Anak Usia Dini. Penulis juga aktif mengajar di beberapa universitas sebagai dosen luar biasa, yaitu Universitas Khairun dan Universitas Terbuka (UBPJJ-Ternate) Program Studi Pendidikan Anak Usia Dini. 